See discussions, stats, and author profiles for this publication at: https://www.researchgate.net/publication/314097894

\title{
Effect of growth path on the performance and carcass traits of Hereford steers finished either on pasture or in feedlot
}

Article in Animal Production Science · January 2017

Dol: 10.1071/AN16061

\section{CITATION}

1

8 authors, including:

Elisa Peripolli

São Paulo State University

49 PUBLICATIONS 70 CITATIONS

SEE PROFILE

Pereira Angélica Simone Cravo

University of São Paulo

85 PUBLICATIONS 284 CITATIONS

SEE PROFILE

Some of the authors of this publication are also working on these related projects:

Consorcio Regional de Innovación en Lanas Ultrafinas View project

Project Mortalidad perinatal de corderos View project
Georgget Banchero

National Institute of Agricultural Research of Uruguay

27 PUBLICATIONS 17 CITATIONS

SEE PROFILE

-8) Gustavo Brito

National Institute of Agricultural Research of Uruguay

60 PUBLICATIONS 663 CITATIONS

SEE PROFILE 


\title{
Effect of growth path on the performance and carcass traits of Hereford steers finished either on pasture or in feedlot
}

\author{
Elisa Peripolli ${ }^{\mathrm{A}, \mathrm{D}}$, Georgget Banchero ${ }^{\mathrm{B}}$, Angélica Simone Cravo Pereira ${ }^{\mathrm{C}}$, Gustavo Brito ${ }^{\mathrm{B}}$, \\ Alejandro La Manna ${ }^{\mathrm{B}}$, Enrique Fernandez ${ }^{\mathrm{B}}$, Fabio Montossi ${ }^{\mathrm{B}}$ and Fernando Baldi ${ }^{\mathrm{A}}$ \\ AUniversidade Estadual Paulista, FCAV, Departamento de Zootecnia, Jaboticabal, 14884-900, Brazil. \\ ${ }^{\mathrm{B}}$ Instituto Nacional de Investigación Agropecuária (INIA), Colonia, 70000, Uruguay. \\ CUniversidade de São Paulo, Departamento de Nutrição e Produção Animal, Pirassununga, 13635-900, Brazil. \\ ${ }^{\mathrm{D}}$ Corresponding author. Email: elisa_peripolli@hotmail.com
}

\begin{abstract}
The objective of the present study was to evaluate the effect of nutritional management treatments during the rearing period on the performance and carcass traits of Hereford steers finished either on pasture or in feedlot. Two hundred and forty male Hereford calves, weaned at 8 months of age with an average weight of $170 \pm 17 \mathrm{~kg}$, were used. After weaning, four nutritional treatments were imposed on the calves so as to obtain different daily liveweight gains ( $\mathrm{LWGs,} \mathrm{kg} / \mathrm{day}$ ) during the first winter (winter-growth phase). The nutritional management groups were high LWG in feedlot (HF), low LWG in feedlot (LF), high LWG on pasture (HP) and low LWG on pasture (LP). Finishing phase began when each group reached a mean liveweight (LW) of $350 \pm 28 \mathrm{~kg}$. During this phase, one half of the HF, LF, HP and LP animals were finished on pasture and the other half in feedlot. The animals were slaughtered when each group attained a mean LW of $500 \mathrm{~kg}$. The carcass traits ribeye area $\left(\mathrm{cm}^{2}\right)$ and backfat thickness $(\mathrm{mm})$ were measured by ultrasonography. Liveweight, LWG and ultrasonography records were analysed by repeated-measures analysis. DM intake as a percentage of LW and feed conversion ratio (FCR; kg $\mathrm{DM} / \mathrm{kg} \mathrm{LW}$ ) during feedlot were analysed by ANOVA. Least-square means for LWGs of pasture-finished animals were $0.807,0.799,0.819 \mathrm{c}$ and $0.782 \mathrm{~kg} /$ day for HF, LF, HP and LP respectively. Least-square means for LWG of feedlot-finished animals were $1.569,1.554,1.484$ and $1.431 \mathrm{~kg} /$ day for HF, LF, HP and LP respectively. Least-square means for FCR in feedlot were 7.12, 7.20, 7.97 and 8.92 for HF, LF, HP and LP respectively. Hot carcass weight had a similar trend as did LWG. Feedlot-finished animals attained heavier hot carcass weights once they received a better nutritional management during the first winter. The growth-group management did not affect $(P>0.05)$ dressing percentage. The carcasses of feedlotfinished animals showed higher $(P<0.05)$ dressing percentages than did carcasses of pasture-finished animals. Nutritional feeding management during the first winter had permanent effects on growth, carcass and FCR traits; however, the prevalence of these effects depended on the feeding system during the finishing phase. On the basis of the results obtained in the study, it is recommended that animals receive an adequate nutritional management during the first winter so as to maximise their future performance, especially for intensive beef-cattle growing-finishing systems. However, if the animals have been subjected to restriction during early growth, they should be finished under pasture conditions.
\end{abstract}

Additional keywords: beef cattle, carcass composition, compensatory gain, feed conversion ratio, finishing system, grow-out.

Received 2 February 2016, accepted 2 December 2016, published online 28 February 2017

\section{Introduction}

Beef-cattle rearing and fattening systems in South America are performed mainly on grazing, native or improved pastures. In Uruguay, particularly in the south-western part of the country, $\sim 60-70 \%$ of the grazing area used for cattle rearing and finishing is based on improved pastures, mix of grasses and legumes of cool season. Despite the good quality of these pastures, their growth rate might be limited by environmental conditions due to low temperatures and a short photoperiod (Cozzolino et al. 1994). There are several alternatives and strategies to overcome scarce forage production (Risso et al. 1991; Vaz Martins et al. 2005; Beretta et al. 2006). However, most of the research has been focussed on finishing systems, without considering the effects of winter nutrition during rearing on subsequent finishing performance. The impact of improvement in nutritional status immediately after weaning on animal performance, tissuedeposition pattern and feed conversion ratio (FCR) during the finishing phase has been widely reported (Parks 1982; Owens et al. 1995; Dicker et al. 2001; Robinson et al. 2001; Purchas et al. 2002). Therefore, better nutrition throughout the inclusion of the feedlot at an early stage can influence the rate and pattern of animal tissue deposition, and modify the type of final product obtained. Moreover, beef industry is demanding heavier carcasses with a greater degree of fattening, situation that has 
forced farmers to use energy and protein supplements for animals under more intensive feeding, either through supplementation on pastures or under feedlot conditions. There is no information available about how differences in growth rate before the finishing phase affect animal performance and carcass attributes of cattle finished under temperate conditions. Therefore, the objective of the present study was to assess the effect of nutritional management during the rearing period on the performance and carcass traits of pasture-finished or feedlotfinished Hereford cattle.

\section{Materials and methods}

The experiment was conducted at the National Institute for Agricultural Research (INIA) experimental station 'La Estanzuela' $\left(34^{\circ} 28^{\prime} \mathrm{S}, \quad 57^{\circ} 51^{\prime} \mathrm{W}\right)$, Colonia, Uruguay, in accordance with the Experimental Unit directive concerning the use of Animals for Experimentation of INIA. In total, 240 male Hereford calves that had been castrated, weaned at 8 months of age (at the end of March 2008), and had an initial mean liveweight (LW) of $170 \pm 17 \mathrm{~kg}$, were used. After weaning, calves were kept together and grazed native pastures $(70 \mathrm{~g}$ of protein and 7.9 MJ of metabolisable energy (ME) per $\mathrm{kg} \mathrm{DM}$ ), and were offered alfalfa hay (Medicago sativa) for 25 days before the start of the experiment in May of 2008. The experiment had three phases (Fig. 1). The winter-growth phase ran throughout 2008 (93 days), followed by the compensatory phase that ran throughout 2008 and 2009 (196 days), and the finishing phase, which began in March 2009 and ended in September of the same year (193 days) when the animals were slaughtered at a mean LW of $500 \mathrm{~kg}$.

\section{Winter-growth and compensatory phases}

At the beginning of the winter-growth phase, four nutritional treatments were imposed to the calves, including two treatments based on feedlot diet and two based on pasture diets. These treatment groups were established to assess the effect of divergent growth (LWG, kg/day) during grow-out (from 31 May to 1 September; 93 days) on the growth and fattening during finishing. The nutritional management groups were high LWG in feedlot (HF), low LWG in feedlot (LF), high LWG in pasture (HP) and low LWG in pasture (LP). For this and at weaning, calves were stratified by LW and randomly sorted into four experimental groups of 60 animals each. The target LWGs during the first winter were $1.00,0.70,0.60$ and $0.30 \mathrm{~kg} /$ day for HF, LF, HP and LP groups respectively. These LWGs were predicted according to the nutritional requirements recommended by Agricultural and Food Research Council (1993).

Calves from HF and LF groups were allocated into 20 pens, 10 pens per management group (6 calves/pen, $14.25 \mathrm{~m}^{2} /$ animal). Both groups received a diet on a DM basis, composed of $80 \%$ of concentrate and $20 \%$ of foxtail millet hay (Setaria Italica). For both groups, the crude protein of the diet was $16 \%$, and the energy concentrations of the diet for HF and LF were 11.4 and 10.5 MJ $\mathrm{ME} / \mathrm{kg} \mathrm{DM}$ respectively. Calves were subjected to a diet and management-adaptation period for 15 days. The chemical and nutritional composition of hay and concentrate for $\mathrm{HF}$ and $\mathrm{LF}$ groups are presented in Table 1.

Calves reared on pasture, namely HP and LP groups, were offered 5 and $2.5 \mathrm{~kg} \mathrm{DM} / 100 \mathrm{~kg} \mathrm{LW}$ of forage allowance (FA) daily respectively. The pasture used was oat (Avena sativa) with an average availability of $2200 \mathrm{~kg} \mathrm{DM} / \mathrm{ha}(19.6 \%$ of DM and mean forage height of $28.8 \mathrm{~cm}$ ). Pasture was grazed in daily strips,
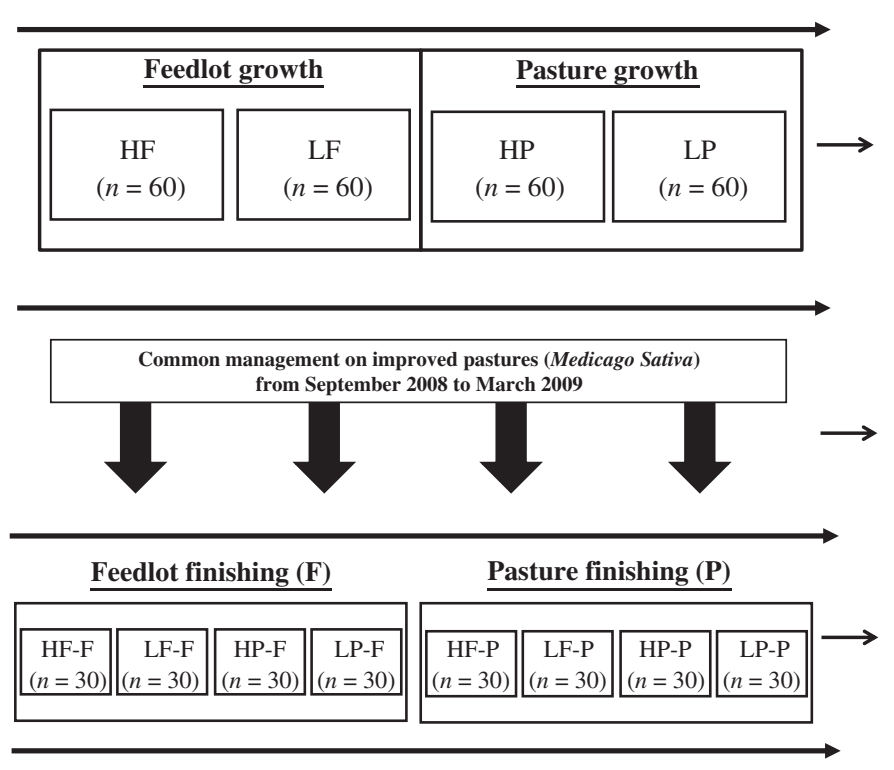

Weaning: March 2008 $170 \mathrm{~kg} \mathrm{LW}-8$ months of age

\section{WINTER GROWTH PHASE (93 days):}

31 May-1 September 2008

End of first winter: September 2008 207 to $273 \mathrm{~kg} \mathrm{LW}-13$ months of age

COMPENSATORY PHASE (196 days):

2 September 2008 - 15 March 2009

\section{FINISHING PHASE (193 days): \\ 16 March - 26 September 2009} $350 \mathrm{~kg} \mathrm{LW}-20$ months of age

Slaughter: September 2009 $500 \mathrm{~kg} \mathrm{LW}-23-26$ months of age

Fig. 1. Flowchart of nutritional management groups during the winter-growth, compensatory and finishing phases. HF, high liveweight gain in feedlot; HP, high liveweight gain on pasture; LF, low liveweight gain in feedlot; LP, low liveweight gain on pasture. 
Table 1. Chemical and nutritional composition of the ration components and forage utilised during the wintergrowth and finishing phases (explained in Fig. 1)

The \%values are expressed as \% of DM. Methods used were as per Van Soest (1982), and Kjeldahl method. CP, crude protein; ADF, acid detergent fibre; NDF, neutral detergent fibre; ME, metabolic energy; HF, high liveweight gain in feedlot; LF, low liveweight gain in feedlot

\begin{tabular}{|c|c|c|c|c|c|}
\hline \multirow[t]{2}{*}{ Parameter } & \multicolumn{5}{|c|}{ Chemical and nutritional composition } \\
\hline & $\mathrm{CP}(\%)$ & $\mathrm{ADF}(\%)$ & NDF $(\%)$ & Ashes $(\%)$ & $\mathrm{ME}(\mathrm{MJ} / \mathrm{kg} \mathrm{DM})$ \\
\hline \multicolumn{6}{|c|}{ Winter growth phase feedlot growing } \\
\hline \multicolumn{6}{|l|}{ Ration composition } \\
\hline Moha hay (Setaria Italica) & 6.59 & 48.7 & 71.0 & 13.2 & 7.4 \\
\hline Concentrate for HF group ${ }^{\mathrm{A}}$ & 21.4 & 8.30 & 19.5 & 4.30 & 12.4 \\
\hline Concentrate for LF group ${ }^{\mathrm{B}}$ & 20.7 & 19.5 & 37.4 & 5.80 & 11.2 \\
\hline \multicolumn{6}{|c|}{ Winter growth phase: pasture growing } \\
\hline \multicolumn{6}{|l|}{ Pasture composition } \\
\hline Oat forage for HP group & 21.00 & 31.00 & 49.00 & 12.00 & 9.6 \\
\hline Oat forage for LP group & 19.00 & 32.00 & 53.00 & 12.00 & 9.5 \\
\hline \multicolumn{6}{|c|}{ Finishing Phase: feedlot finishing } \\
\hline \multicolumn{6}{|l|}{ Ration composition } \\
\hline Concentrate $\mathrm{C}^{\mathrm{C}}$ & 11.8 & 18.6 & 30.8 & 8.4 & 11.3 \\
\hline Moha hay (Setaria Italica) & 6.7 & 50.4 & 72.0 & 12.5 & 7.1 \\
\hline \multicolumn{6}{|c|}{ Finishing Phase: pasture finishing } \\
\hline \multicolumn{6}{|l|}{ Pasture composition } \\
\hline Alfalfa (63 days) & 19.1 & 43.2 & 50.4 & 0.96 & 1.95 \\
\hline Oat (60 days) & 11.4 & 36.1 & 52.1 & 0.52 & 2.35 \\
\hline Alfalfa (30 days) & 23.2 & 37.8 & 45.2 & 0.74 & 2.23 \\
\hline
\end{tabular}

\footnotetext{
${ }^{\mathrm{A}}$ Composed of maize grain, soybean pellets, calcium carbonate, salt, dicalcium phosphate, sodium bicarbonate, magnesium oxide and urea.

${ }^{\mathrm{B} C}$ Composed of sorghum grain, wheat bran, sunflower pellets, calcium carbonate, salt, dicalcium phosphate, sodium bicarbonate, magnesium oxide and urea.

${ }^{\mathrm{C}}$ Composed of maize grain, sorghum grain, wheat bran, soybean pellets, calcium carbonate, salt, dicalcium phosphate, sodium bicarbonate, magnesium oxide and urea.
}

and animals were not allowed to return to the previously grazed areas. The FA was adjusted weekly and treatmentstrip areas were delimited by an electric fence. The area to be grazed in the following week was determined on the basis of weekly DM biomass estimation and the latest animal LW record.

To determine forage availability, a double-weight sampling method was used (Gardner 1967), using a three-value scale (1 for lowest forage biomass; 3 for greatest forage biomass). Using these reference-scale levels, pasture biomass was assessed at random points in the area $(800$ points/ha) by throwing a 50 by $20 \mathrm{~cm}$ iron rectangle. Scale-level samples were cut at ground level, dried at $60^{\circ} \mathrm{C}$ until a constant weight was achieved, and mean biomass was calculated from the relative frequency of occurrence of each biomass-scale level. The same technique was used every 7 days, during three consecutive days, to estimate pre- and post-grazing forage DM biomass in the daily strip used. The oat forage nutritional and chemical compositions are presented in Table 1.

After winter and until the start of autumn, all groups of animals (HC, LC, HP and LP) were managed together on alfalfa pasture (Medicago Sativa); this period was called a compensatory phase. In spring, steers were offered $5.0 \mathrm{~kg} \mathrm{DM} / 100 \mathrm{~kg} \mathrm{LW}$ of alfalfa and, in summer, the allowance was reduced to $4 \mathrm{~kg} \mathrm{DM} / 100 \mathrm{~kg}$ LW due to a severe drought.
Finishing phase

Finishing phase began when each growth-management group (HC, LC, HP and LP) reached a minimum mean LW of $350 \pm$ $28 \mathrm{~kg}$. This target LW is normally used by Uruguayan farmers as a criterion to enter the animals into the feedlot. During this phase, each growth-management group was divided into two groups, with one half of the animals being finished on pasture and the other half in feedlot. Within each management group, the animals were stratified by LW, and were drawn randomly to feedlot- or pasture-finishing system. As a result of the combination of the first-winter management groups (HF, LF, HP and LP) and the finishing systems, feedlot or pasture, a total of eight treatments arrangements was established (Fig. 1).

Feedlot-finished steers were allocated into 40 pens ( 3 steers/ pen), resulting in 10 pens per each growth-management group. Feedlot-finished steers were subjected to a diet and managementadaptation period of 15 days. After the adaptation period, the amount of feed offered was adjusted by the slick bunk method. This method involves quantifying the amount of remaining feed (concentrate and hay) early in the morning, before feeding of the animals. The amount of feed offered was increased by $5 \%$ (DM basis) when left-overs were not observed in the trough for a period of 3 days. The total feed was offered in two meals, in the morning and in the afternoon, and feed refusal was collected in the morning to determine pen consumption. The difference between 
feed offered and feed refused was used to estimate DM intake (DMI) as a percentage of LW and FCR ( $\mathrm{kg} \mathrm{DM} / \mathrm{kg} \mathrm{LW})$ per pen.

The diet was composed of a commercial concentrate and foxtail millet hay (Setaria italica), at proportions of $80 \%$ and $20 \%$ (on a DM basis) respectively. Samples from the concentrate and hay were analysed to determine chemical and nutritional composition (Table 1).

Pasture-finished steers were offered 5\% FA daily. The pasture used during the finishing phase was alfalfa (Medicago sativa) and oat grass (Avena sativa). The pasture management and forage availability were the same as described before for growth phase. Forage samples were analysed to determine chemical and nutritional composition at the beginning, middle and end of the experiment (Table 1).

The main objective during the finishing phase was to obtain high LWGs, either in pasture or in feedlot, so as to reach the target slaughter weight as soon as possible. As a result of differences in the LWG achieved during the first winter, HF and LF groups reached the target LW before the HP and LP groups did; therefore, HF and LF groups started the finishing phase 1 month earlier. Steers were slaughtered once each growth-management group (HF, LF, HP and LP), feedlot- or pasture-finished, attained a minimum mean LW of $500 \mathrm{~kg}$. Animals were slaughtered in the following order: HF and LF groups finished in feedlot, HP and LP finished in feedlot, HF and LF groups finished on pasture, and HP and LP finished on pasture. The four slaughters were performed in the same commercial slaughterhouse, in accordance with the Uruguayan inspection service procedures (Ministry of Livestock, Agriculture and Fishery, MGAP). The animals were transported a distance of $160 \mathrm{~km}$ to the slaughterhouse by trucks, and remained in the slaughterhouse less than $12 \mathrm{~h}$ before being slaughtered. In the slaughterhouse, the animals were offered fresh water ad libitum.

\section{Measurements}

Cattle were weighed at the beginning of the experiment and every 14 days ( \pm 3 days) till the end of the experiment, always during the same hour in the morning, without fasting. Ribeye area $\left(\mathrm{REA}, \mathrm{cm}^{2}\right.$ ) and backfat thickness (BFT, $\mathrm{mm}$ ) were assessed at the beginning, middle and at end of the finishing phase. REA and BFT were measured by ultrasonography at the 12th rib. An Aloka 500 ultrasound equipment (Aloka Co., Tokyo, Japan), equipped with a $3.5-\mathrm{MHz}, 17.2-\mathrm{cm}$ linear transducer, was used to access REA and BFT, and an acoustic coupler (standoff pad) was used to obtain the real-time ultrasound images, collected according to the methodology approved by Ultrasound Guidelines Council (http://www.ultrasoundbeef.com/, accessed 11 November 2015), described in the Beef Improvement Federation guidelines (BIF 1996). At the slaughterhouse, hot carcass weight (HCW), cold carcass weight $(\mathrm{HCW})$ and dressing percentage (DP) were determined.

\section{Statistical analyses}

The objective of the present study was to assess the effect of nutritional management in the rearing period on the performance and carcass traits in the finishing phase. Thus, the records at the growth and finishing phases were analysed separately. The LW, LWG and ultrasonography records at the growing and finishing phases were analysed by repeated-measures analysis over time, using SAS (SAS Institutue Inc., Cary, NC, USA), with the PROC MIXED procedure, and by applying the restricted maximumlikelihood method. For the traits assessed during the growth phase, the model included the day of measurement, the nutritional management group at the growing phase (HF, LF, HP and LP), the interaction between growth-management groups and the day of measurement as fixed effects, and the linear covariable LW at the beginning of the growing phase.

For the traits assessed in the finishing phase, the model included as fixed effects the day of measurement, the nutritional management group at the growth phase (HF, LF, HP and LP), the type of finishing (feedlot or pasture), the interaction between management group at the growing and finishing phases, and the linear covariable LW at the end of the growth phase. Only significant $(P<0.05)$ interactions were considered in the model. Tukey test was applied to compare the means $(P<0.05)$.

For repeated-measure traits, different structures were tested to model the residual covariance matrices. To select the most adequate covariance structure to model the residuals, the Schwarz Bayesian (BIC; Wolfinger 1993) was used. To perform the statistical analyses for $\mathrm{HCW}, \mathrm{HCW}$ and DP, the model included as fixed effects the nutritional management groups at the growth phase (HF, LF, HP and LP), nutritional management groups at the finishing phase (feedlot or pasture), the interaction between management groups at the growing and finishing phases, and the linear covariable LW at the end of the growing phase. For feedlot-finished animals, to analyse the DMI as a percentage of LW and FCR during the feedlot finishing, the model included the fixed effects of nutritional management at the growth phase (HF, LF, HP and LP), and the linear covariable LW at the end of the growth phase. For these traits, the pen composed by three steers was considered as the experimental unit. Only significant $(P<0.05)$ interactions were considered in the model. Tukey test was applied to compare the means $(P<0.05)$.

\section{Results and discussion}

\section{Winter-growth and compensatory phase}

Liveweight gain was significantly different among management groups and greater than expected when the treatments were established (Table 2). Differences between the expected and observed LWGs at the end of first winter were probably due to favourable weather conditions during winter, with higher temperatures and lower rainfall than in an average year. Previous studies have reported similar differences in LW at the end of the growth phase for steers reared on different postweaning growth pathways (Ridenour et al. 1982; Sainz et al. 1995; Dicker et al. 2001; Robinson et al. 2001; Loken et al. 2009).

During the compensatory phase, there were significant differences in LWG among groups, with LF, HP and LP groups showing different degrees of compensatory growth (Table 2). Sainz et al. (1995) and Drouillard and Kuhl (1999) have suggested that differences in growth feed management might be associated with different degrees of compensatory growth after a nutritional restriction period. In some studies, it was observed that cattle are able to make a great compensatory 
growth on pasture following a nutritional restriction in the previous winter (Bohman 1955; Meyer et al. 1965; Horton and Holmes 1978). These statements are supported by the concept that compensatory growth is inversely related to the severity of the restriction (Ryan 1990), as observed for HP and LP groups, which compensated growth after winter restriction. Effects of previous nutrition management on subsequent growth and development have been well documented in earlier studies (Wilson and Osbourn 1960; Allden 1970; O'Donovan 1984). Summer LWGs were lower than spring LWGs, probably as a consequence of $\mathrm{FA}$ reduction, from $5 \%$ to $4 \%$, and there were no significant $(P>0.05)$ differences among the management groups (Table 2).

During growth phase, differences in REA and BFT evolution among groups were observed (results not shown). At the end of the growth phase, HF and LF groups had a greater REA and similar BFT than did HP and LP management groups (Table 3). According to Carstens (1995), compensatory growth has been associated with lean/fat content in beef cattle. Even though Sainz et al. (1995) and Robinson et al. (2001) observed a greater degree of fatness in the better fed cattle, this difference was not observed in the present experiment. One reason for the divergence between these results might be related to the growth period established in each study. According to Ball et al. (1997) and Berg and Butterfield (1976), cattle slaughtered within the compensatory growth phase have fat and lean contents different from those expected for their weight, since immediately after the catch-up growth period, there is a reduction in fat deposition.
Finishing phase

There were significant $(P<0.05)$ differences among management groups for LW at the beginning of the finishing phase (Table 2). Thus, to analyse the traits measured during this phase, LW at the beginning of the finishing phase was included as a covariable in the model. Moreover, the time to reach the target weight at the beginning of the finishing phase was different among management groups. Similar to our results, Ridenour et al. (1982) observed that steers fed high-concentrate diets during the growing phase required fewer days to achieve 273-kg LW than did those fed a lowerconcentrate diet and a pasture-based diet. Thus, supplementary feeding in winter-early spring is necessary to overcome the limitations of winter feed gaps and to reduce the period of feedlot entry (Dicker et al. 2001). For all management groups, the LWG during the finishing phase was inversely related to pre-finishing LWG. As expected, LWGs for feedlot-finished animals were greater than those for pasture-finished ones (Table 4). The interaction between growth-management groups during the first winter and finishing phases (feedlot or pasture) significantly $(P<0.05)$ affected the LWG during the finishing phase. For pasture-finished animals, no significant $(P>0.05)$ differences in LWG were observed among growth-management groups. Nevertheless, for feedlot-finished animals, HF and LF groups showed greater LWGs than did HP and LP groups. These results demonstrated that, particularly for feedlot-finished animals with high-energy diets, the nutritional management during the growing phase significantly affected the weight evolution during the finishing phase. Similar results were observed by Robinson

Table 2. Least-square means \pm standard errors for seasonal daily liveweight gain (LWG, $\mathrm{kg} / \mathrm{day}$ ), and LW at the end of the wintergrowth phase (LWEWG) and at the end of the compensatory phase (LWEC) of the growth-management groups HF, high LWG in feedlot; LF, low LWG in feedlot; HP, high LWG on pasture; LP, low LWG on pasture. Winter, June-August; spring, September, October and November; summer, December-February. Means within a column followed by the same letter not significantly different (at $P=0.05)$

\begin{tabular}{lcccrr}
\hline $\begin{array}{l}\text { Winter-growth } \\
\text { phase }\end{array}$ & $\begin{array}{c}\text { Winter LWG 10-13 } \\
\text { months of age }\end{array}$ & LWEWG & $\begin{array}{c}\text { Spring LWG 14-16 } \\
\text { months of age }\end{array}$ & $\begin{array}{c}\text { Summer LWG 17-19 } \\
\text { months of age }\end{array}$ & LWEC \\
\hline HF & $1.092 \pm 0.0325 \mathrm{a}$ & $273 \pm 2.110 \mathrm{a}$ & $0.829 \pm 0.0255 \mathrm{~b}$ & $0.302 \pm 0.0299 \mathrm{a}$ & $362 \pm 2.500 \mathrm{a}$ \\
LF & $0.782 \pm 0.0325 \mathrm{~b}$ & $243 \pm 2.150 \mathrm{~b}$ & $0.921 \pm 0.0255 \mathrm{a}$ & $0.333 \pm 0.0301 \mathrm{a}$ & $350 \pm 2.503 \mathrm{~b}$ \\
HP & $0.537 \pm 0.0325 \mathrm{c}$ & $224 \pm 2.091 \mathrm{c}$ & $0.873 \pm 0.0255 \mathrm{a}$ & $0.356 \pm 0.0288 \mathrm{a}$ & $364 \pm 2.475 \mathrm{a}$ \\
LP & $0.352 \pm 0.0325 \mathrm{~d}$ & $207 \pm 2.088 \mathrm{~d}$ & $0.910 \pm 0.0255 \mathrm{a}$ & $0.405 \pm 0.0279 \mathrm{a}$ & $351 \pm 2.436 \mathrm{~b}$ \\
\hline
\end{tabular}

Table 3. Least-square means and standard errors for ribeye area (REA) and backfat thickness (BFT) measured at the 12th rib by ultrasound, during the feedlot- and pasture-finishing phases of growth-management groups

The least-square means were weight-adjusted to a common liveweight at the beginning of the finishing phase. The REA and BFT were measured at the beginning, middle (45 days for feedlot finishing and 90 days for pasture finishing) and end (slaughter) of the finishing phase. HF, high liveweight gain in feedlot; LF, low liveweight gain in feedlot; HP, high liveweight gain on pasture; LP, low liveweight gain on pasture. Means within a column followed by the same letter are not significantly different (at $P=0.05$ )

\begin{tabular}{|c|c|c|c|c|c|c|c|c|}
\hline \multirow{2}{*}{$\begin{array}{l}\text { Winter-growth } \\
\text { phase }\end{array}$} & \multirow{2}{*}{$\begin{array}{l}\text { Finishing } \\
\text { phase }\end{array}$} & \multirow[t]{2}{*}{$n$} & \multicolumn{3}{|c|}{$\operatorname{REA}\left(\mathrm{cm}^{2}\right)$} & \multicolumn{3}{|c|}{ BFT (mm) } \\
\hline & & & Initial & Middle & Final & Initial & Middle & Final \\
\hline $\mathrm{HF}$ & Feedlot & 30 & $51.61 \pm 0.701 \mathrm{a}$ & $62.52 \pm 0.799 \mathrm{a}$ & $66.94 \pm 0.890 \mathrm{a}$ & $2.37 \pm 0.125 \mathrm{a}$ & $5.99 \pm 0.231 \mathrm{a}$ & $8.59 \pm 0.330 a$ \\
\hline LF & & 30 & $49.08 \pm 0.690 \mathrm{ab}$ & $59.46 \pm 0.788 \mathrm{ab}$ & $63.97 \pm 0.861 \mathrm{ab}$ & $2.49 \pm 0.116 \mathrm{a}$ & $5.67 \pm 0.221 \mathrm{ab}$ & $9.22 \pm 0.329 a$ \\
\hline LP & & 30 & $47.00 \pm 0.704 b$ & $58.23 \pm 0.808 \mathrm{~b}$ & $63.84 \pm 0.900 \mathrm{ab}$ & $2.69 \pm 0.120 \mathrm{a}$ & $5.33 \pm 0.239 \mathrm{ab}$ & $8.24 \pm 0.347 a$ \\
\hline $\mathrm{HF}$ & Pasture & 30 & $50.8 \pm 0.735 \mathrm{ab}$ & $54.39 \pm 0.830 \mathrm{bc}$ & $61.22 \pm 0.943 b$ & $2.80 \pm 0.120 \mathrm{a}$ & $3.82 \pm 0.248 b$ & $6.25 \pm 0.358 b$ \\
\hline LF & & 30 & $49.70 \pm 0.746 \mathrm{ab}$ & $51.82 \pm 0.831 \mathrm{c}$ & $61.56 \pm 0.934 b$ & $2.48 \pm 0.124 a$ & $3.88 \pm 0.247 b$ & $5.92 \pm 0.345 b$ \\
\hline
\end{tabular}


Table 4. Least-square means and standard errors for daily liveweight gain (LWG), final LW (FLW), hot carcass weight (HCW), dressing percentage (DP) and cold carcass weight (CCW) during the finishing phase according to management groups

The least-square means were weight-adjusted to a common LW at the beginning of the finishing phase. HF, high LWG in feedlot; LF, low LWG in feedlot; HP, high LWG on pasture; LP, low LWG on pasture. Means within a column followed by the same letter are not significantly different (at $P=0.05$ )

\begin{tabular}{|c|c|c|c|c|c|c|c|}
\hline Winter-growth phase & Finishing phase & $n$ & LWG (kg/day) & FLW (kg) & HCW (kg) & DP (\%) & $\mathrm{CCW}(\mathrm{kg})$ \\
\hline $\mathrm{HF}$ & Feedlot & 30 & $1.569 \pm 0.0253 \mathrm{a}$ & $503.8 \pm 2.92 \mathrm{a}$ & $256.3 \pm 1.601 \mathrm{a}$ & $50.0 \pm 0.251 \mathrm{a}$ & $247.1 \pm 1.571 \mathrm{a}$ \\
\hline LF & & 30 & $1.554 \pm 0.0253 \mathrm{a}$ & $499.3 \pm 2.92 \mathrm{a}$ & $253.7 \pm 1.592 \mathrm{ab}$ & $50.7 \pm 0.251 \mathrm{a}$ & $245.0 \pm 1.569 \mathrm{ab}$ \\
\hline HP & & 30 & $1.484 \pm 0.0244 b$ & $501.7 \pm 3.10 \mathrm{a}$ & $249.8 \pm 1.655 \mathrm{ab}$ & $50.4 \pm 0.267 a$ & $241.1 \pm 1.623 \mathrm{ab}$ \\
\hline LP & & 30 & $1.431 \pm 0.0244 b$ & $492.1 \pm 3.09 \mathrm{a}$ & $247.6 \pm 1.626 b$ & $51.8 \pm 0.268 \mathrm{a}$ & $238.9 \pm 1.590 \mathrm{~b}$ \\
\hline $\mathrm{HF}$ & Pasture & 30 & $0.807 \pm 0.0178 \mathrm{c}$ & $505.6 \pm 3.21 \mathrm{a}$ & $246.4 \pm 1.711 b$ & $48.7 \pm 0.273 b$ & $241.6 \pm 1.687 \mathrm{ab}$ \\
\hline LF & & 30 & $0.799 \pm 0.0178 \mathrm{c}$ & $507.3 \pm 3.21 \mathrm{a}$ & $247.0 \pm 1.723 b$ & $48.5 \pm 0.274 b$ & $241.7 \pm 1.690 \mathrm{ab}$ \\
\hline HP & & 30 & $0.819 \pm 0.0180 \mathrm{c}$ & $506.4 \pm 3.21 \mathrm{a}$ & $247.8 \pm 1.688 b$ & $49.0 \pm 0.273 b$ & $243.7 \pm 1.667 \mathrm{ab}$ \\
\hline LP & & 30 & $0.782 \pm 0.0180 \mathrm{c}$ & $505.9 \pm 3.09 \mathrm{a}$ & $249.2 \pm 1.629 b$ & $49.0 \pm 0.276 b$ & $244.9 \pm 1.590 \mathrm{ab}$ \\
\hline
\end{tabular}

et al. (2001), who also found that growth pathway and finishing system can affect cattle finishing gain. These authors showed that feedlot-finished cattle had greater LWGs than did pasture-finished cattle; however, in disagreement with our results, animals that were restricted during the growth period showed greater LWGs during finishing than did non-restricted ones. Likewise, Loerch (1990) observed that steers whose intake was restricted during the growing phase showed higher gains on subsequent finishing phase than did those fed with corn silage ad libitum. In accordance with our results, Lewis et al. (1990) reported higher LWGs in finishing phase for cattle that received better feeding during the first winter.

As expected, there were no effects of growing- and finishingphase management on the final LW, since the criteria adopted to slaughter the animals was the same for all treatments (at least $500 \mathrm{~kg} \mathrm{LW}$; Table 4). However, the steers belonging to HF and LF groups finished on pasture or in feedlot were slaughtered 30 and 40 days earlier than were their counterparts in HP and LP. The interaction between the nutritional management in the growing phase and that in the finishing phase was significant $(P<0.01)$ for HCW. The results obtained for HCW followed a tendency similar to those obtained for LWG in the finishing phase. For pasture-finished animals, the management group during rearing period did not influence the HCW. However, differences were observed within feedlot-finished animals, in which steers that received a better nutritional management during their first winter attained a heavier HCW. Growthgroup management did not affect $(P>0.05)$ DP.

DM intake as a percentage of LW during the finishing period and for animals finished under feedlot was higher for HF and lower for HP and LP management groups (Table 5). Thus, the nutritional management during the first winter affected DMI during feedlot finishing. The FCR during the finishing phase was higher $(P<0.05)$ for LP management group, requiring more feed to gain one unit of LW than in the other groups. As nutritional management in the first winter was enhanced, a trend to improve FCR in the feedlot treatments was observed, probably due to higher LWGs of animals in HF, LF and HP management groups during feedlot finishing (Table 5). According to Dikeman (1973), feeding cattle at the maximum gain rate decreases FCR because of the dilution of animal's maintenance requirements.

Ridenour et al. (1982) observed that FCR of steers fed on high-concentrate diet in the growing phase was lower than those
Table 5. Least-square means for daily DM intake (DMI) as a percentage of liveweight (LW) and feed conversion ratio (FCR) during the feedlotfinishing phase of growth-management groups

The least-square means were weight-adjusted to a common LW at the beginning of the finishing phase. HF, high LW gain in feedlot; LF, low LW gain in feedlot; HP, high LW gain on pasture; LP, low LW gain on pasture. Means within a column followed by the same letter are not significantly different (at $P=0.05$ )

\begin{tabular}{lccc}
\hline Winter-growth phase & $n$ & DMI $(\% \mathrm{LW})$ & FCR $(\mathrm{kg} \mathrm{DM} / \mathrm{kg} \mathrm{LW})$ \\
\hline HF & 30 & $2.86 \pm 0.112^{\mathrm{a}}$ & $7.12 \pm 0.453^{\mathrm{b}}$ \\
LF & 30 & $2.75 \pm 0.112^{\mathrm{ab}}$ & $7.20 \pm 0.453^{\mathrm{b}}$ \\
HP & 30 & $2.62 \pm 0.112^{\mathrm{b}}$ & $7.97 \pm 0.453^{\mathrm{b}}$ \\
LP & 30 & $2.61 \pm 0.112^{\mathrm{b}}$ & $8.92 \pm 0.453^{\mathrm{a}}$ \\
\hline
\end{tabular}

of pasture-fed animals, which is in agreement with our results. Regarding the DMI, Loken et al. (2009) studied the effect of bodyweight gain during the backgrounding period on subsequent feedlot-finishing performance and carcass traits on steers. Their results showed that backgrounding treatment had no effect on DMI for low and high LWG (10.73 vs $10.35 \mathrm{~kg}$ /day respectively). Loken et al. (2009) also demonstrated that backgrounding treatment had no effect on DMI and LWG during the finishing phase. Loerch (1990) and Lewis et al. (1990) reported results for DMI similar to those obtained in the present study. Loerch (1990) concluded that DMI for animals finished with the same final diet was $20 \%$ and $30 \%$ lower in animals for which feed intake was restricted in the growing phase, reinforcing the effect of the growth-pathway management on subsequent DMI. Lewis et al. (1990) noticed that during the finishing phase, feed intake and LWG were slightly higher for cattle with superior rates of winter gain; therefore, animals that gained faster during winter tended to eat more and gain faster during the finishing phase.

The interaction between growth management during the first winter and finishing management (feedlot or pasture) significantly $(P<0.05)$ affected REA during the finishing phase (Table 3). For pasture-finished steers, no differences in final REA were observed among growth-management groups. However, for feedlot-finished steers, HF and LF groups showed a greater REA than did HP and LP groups. These results showed that the nutritional management during the first winter 
significantly affected muscle deposition and REA in the subsequent finishing phase. Ridenour et al. (1982) observed significant $(P<0.05)$ differences in REA among treatments with different degrees of energy density in the diet. Animals subjected to a high energy-density diet in the growing phase showed a greater REA in the finishing phase than did those subjected to a lower energy-density diet. The results presented by Ridenour et al. (1982), like those of the present study, indicated that growth management plays a role in the subsequent REA development and the interaction among management groups during first winter and finishing phase affected REA in feedlot-finished animals. The least-square means for BFT during the finishing phase are presented in Table 3. The interaction between the growth-management groups during the first winter and finishing management (feedlot or pasture) did not significantly $(P>0.05)$ affect BFT during the finishing phase. Feedlot-finished animals with high-energy diets showed a higher BFT than did pasture-finished animals, probably due to the effect of the finishing system itself.

In a similar study, Brito et al. (2014) also reported differences in the effect of finishing feeding treatments on carcass and meatquality traits. The finishing feeding system itself had a significant influence on the animal's BFT. BFT was higher $(P<0.05)$ for animals fed concentrate than for grass-fed animals during the fattening period, independently of the nutritional management that animals received during the growing phase. Robinson et al. (2001) also observed the same pattern in which the finishing feeding management, but not the feeding management received during the first winter, had a significant impact on the BFT and intramuscular fat content. BFT over the 12th-13th ribs was markedly reduced by feed restriction, and similar differences were found in abdominal fat weights, carcass fat content, and empty body fat weight (Sainz et al. 1995).

Cattle growth rate during the growing period (first winter) caused several effects on subsequent growth, carcass traits and FCR of feedlot-finished steers. Animals that received an unfavourable nutritional management during the first winter showed compensatory growth in the compensatory phase, reaching, at the end of growth phase, weights similar to those of animals that received a favourable nutritional management in the same growth period. Even though their weights were similar at the end of the growth phase, the unfavourable nutritional management applied in the first winter negatively affected their performance and FCR in the subsequent feedlot-finishing system. For pasture-finished animals, the feeding management during the first winter did not affect their performance and carcass traits in subsequent finishing. This might be related to the fact that under pasture-finishing conditions, steers received a lowerenergy diet. Comparing the results of different studies, Robinson et al. (2001) stated that it is difficult to generalise the effects of early nutritional restriction on subsequent animal growth and carcass composition, because the nutrient supply during the growth period might vary both within and among seasons, and so would the length and intensity of the restriction. Our study took into account several conditions that commonly occur in temperate zones, providing substantial information to assist and guide farmers, technicians and researches in beef-cattle feeding and management programs to make the most affordable decision for livestock production.

\section{Conclusions}

Nutritional feeding management during the first winter has a permanent effect on growth, FCR and carcass traits. However, the prevalence of these effects depends on the feeding system during the finishing phase of animals. On the basis of the results obtained in the present study, it is recommended that the animals could receive adequate nutritional management during the first winter so as to maximise their future performance, especially for intensive beef-cattle growth-finishing systems. However, if the animals have been subjected to restriction during early growth, the recommendation is to finish them under pasture conditions, since the feeding management during the growing phase did not influence the subsequent performance of the pasture-finished animals and because the cost of feed as pasture is lower.

\section{References}

Agricultural and Food Research Council (1993) 'Energy and protein requirements of ruminants.' (CAB International: Wallingford, UK)

Allden WG (1970) The effects of nutritional deprivation on the subsequent productivity of sheep and cattle. Nutrition Abstracts and Reviews 40, 1167-1184.

Ball AJ, Thompson JM, Oddy VH (1997) Nutritional manipulation of body composition and efficiency in ruminants. In 'Proceedings of the Recent advances in animal nutrition'. (Ed. JL Corbett) pp. 192-208. (University of New England: Armidale, NSW)

Beretta V, Simeone A, Elizalde JC, Baldi F (2006) Performance of growing cattle grazing moderate quality legume-grass temperate pastures when offered varying forage allowance with or without grain supplementation. Australian Journal of Experimental Agriculture 46, 793-797. doi:10.1071/EA05331

Berg RT, Butterfield RM (1976) 'New concepts of cattle growth.' (Sydney University Press: Sydney)

BIF (1996) 'Guidelines for uniform beef improvement programs.' (Beef Improvement Federation)

Bohman VR (1955) Compensatory growth of beef cattle: the effect of hay maturity. Journal of Animal Science 14, 249-255. doi:10.2527/jas1955. 141249x

Brito G, San Julián R, La Manna A, Del Campo M, Montossi F, Banchero G, Chalkling D, Soares de Lima JM (2014) Growth, carcass traits and palatability: can the influence of the feeding regimes explain the variability found on those attributes in different Uruguayan genotypes? Meat Science 98, 533-538. doi:10.1016/j.meatsci.2014.07.003

Carstens GC (1995) Compensatory growth in beef cattle. In 'Intake by feedlot cattle symposium'. (Eds F Owens, D Gill, K Lusby, T McCollum) pp. 942-970. (Oklahoma State University: Stillwater, OK)

Cozzolino D, Pigurina G, Methol M, Acosta Y, Mieres J, Bassewitz H (1994) 'Guía para la alimentación de rumiantes. No. 44.' (Unidad de Difusión e Información Tecnológica del INIA: Montevideo, Uruguay)

Dicker RW, Ayres JF, McPhee MJ, Robinson DL, Turner AD, Wolcott ML, Kamphorst PG, Harden S, Oddy VH(2001) Post-weaning growth of cattle in northern New South Wales. 2. Growth pathways of steers. Australian Journal of Experimental Agriculture 41,971-979. doi:10.1071/EA00094

Dikeman ME (1973) Relationship of efficiency of live weight gain and body composition during growth of domestic animals. In '26th reciprocal meat conference of the American Meat Science Association'. pp. 197-222.

Drouillard JS, Kuhl GL (1999) Effects of previous grazing nutrition and management on feedlot performance of cattle. Journal of Animal Science 77, 136-146. doi:10.2527/1999.77suppl_2136x

Gardner AL (1967) 'Estudio sobre métodos agronómicos para la evaluación de pasturas.' (IICA: Montevideo, Uruguay) 
Horton GMJ, Holmes W (1978) Compensatory growth by beef cattle at grassland or on an alfalfa based diet. Journal of Animal Science 46, 297-303. doi:10.2527/jas 1978.461297x

Lewis JM, Klopfenstein TJ, Stock RA (1990) Effects of rate of gain during winter on subsequent grazing and finishing performance. Journal of Animal Science 68, 2525-2529. doi:10.2527/1990.6882525x

Loerch SC (1990) Effects of feeding growing cattle high-concentrate diets at a restricted intake on feedlot performance. Journal of Animal Science $\mathbf{6 8}$, 3086-3095. doi:10.2527/1990.68103086x

Loken BA, Maddock RJ, Stamm MM, Schauer CS, Rush I, Quinn S, Lardy GP (2009) Growing rate of gain on subsequent feedlot performance, meat, and carcass quality of beef steers. Journal of Animal Science 87, 3791-3797. doi:10.2527/jas.2009-1853

Meyer JH, Hull JL, Weitkamp WH, Bonilla S (1965) Compensatory growth responses of fattening steers following various low energy intake regimes on hay or irrigated pasture. Journal of Animal Science 24, 29-37. doi:10.2527/jas1965.24129x

O'Donovan PB (1984) Compensatory gain in cattle and sheep. Nutrition Abstracts and Reviews 54, 389-410.

Owens FN, Gill DR, Secrist DS, Coleman SW (1995) Review of some aspects of growth and development of feedlot cattle. Journal of Animal Science 73, 3152-3172. doi:10.2527/1995.73103152x

Parks JR (1982). 'A theory of feeding and growth of animals.' (SpringerVerlag: Berlin)

Purchas RW, Burnham DL, Morris ST (2002) Effects of growth potential and growth path on tenderness of beef longissimus muscle from bulls and steers. Journal of Animal Science 80, 3211-3221. doi:10.2527/ 2002.80123211x

Ridenour KW, Kiesling HE, Lofgreen GP, Stiffler DM (1982) Feedlot performance and carcass characteristics of beef steers grown and finished under different nutrition and management programs. Journal of Animal Science 54, 1115-1119. doi:10.2527/jas1982.5461115x
Risso DF, Ahunchain M, Cibils R, Zarza A (1991) Suplementación en invernadas del litoral. In 'Pasturas y producción animal en áreas de ganadería intensiva'. (Eds E Restaino, E Indarte) pp. 51-65. No. 15. (Unidad de Difusión e Información Tecnológica del INIA: Montevideo, Uruguay)

Robinson DL, Oddy VH, Dicker RW, McPhee MJ (2001) Post-weaning growth of cattle in northern New South Wales 3. Carry-over effects on finishing, carcass characteristics and intramuscular fat. Australian Journal of Experimental Agriculture 41, 1041-1049. doi:10.1071/EA00093

Ryan WJ (1990) Compensatory growth in cattle and sheep. Nutrition Abstracts and Reviews 19, 653-664.

Sainz RD, Torre FD, Oltjen JW (1995) Compensatory growth and carcass quality in growth restricted and refed beef steers. Journal of Animal Science 73, 2971-2979. doi:10.2527/1995.73102971x

Van Soest PJ (1982) 'Nutritional ecology of ruminant.' (Cornell University Press: New York, NY)

Vaz Martins D, Fernandez E, La Manna A, Mieres J, Banchero G (2005) Efecto del nivel de oferta de forraje y de la suplementación con grano y heno en la performance de novillos que pastoreaban una mezcla de leguminosas y gramíneas durante el otoño. In 'Jornada producción animal intensiva'. (Ed. La Estanzuela, Colonia (Uruguay)) pp. 17-21. No. 406. (Unidad de Difusión e Información Tecnológica del INIA: Montevideo, Uruguay)

Wilson PN, Osbourn DF (1960) Compensatory growth after under nutrition in mammals and birds. Biological Reviews of the Cambridge Philosophical Society 35, 324-361. doi:10.1111/j.1469-185X.1960.tb01327.x

Wolfinger R (1993) Covariance structure selection in general mixed models. Communications in Statistics. Simulation and Computation 22, 1079-1106. doi:10.1080/03610919308813143 